\title{
TINGKAT PENGETAHUAN ORANG TUA TENTANG UPAYA PENCEGAHAN DEMAM BERDARAH PADA ANAK USIA (6-12 thn) DI RUANG MIRAH DELIMA RS WILLIAM BOOTH SURABAYA
}

\author{
Ethyca Sari. Mariana Lalita \\ AKPER William Booth J1.Cimanuk 20.Telp:031-5633365. Email :ethyca.sari@yahoo.com
}

\begin{abstract}
ABSTRAK
Setiap tahun jumlah penderita demam berdarah mengalami peningkatan dan angka kematian kasus ini juga terus mengalami peningkatan, hal ini dikarenakan kurangnya pengetahuan orang tua tentang upaya pencegahan demam berdarah. Mengetahui upaya pencegahan adalah langkah yang paling penting bagi penderita sehingga dapat segera dilakukan tindakan. Berdasarkan hal tersebut penulis tertarik untuk mengambil judul "Gambaran Tingkat Pengetahuan Orang Tua Tentang Upaya Pencegahan Demam Berdarah Pada Anak Usia (6-12 tahun) di Ruang Anak RS William Booth Surabaya". Berdasarkan tujuan peneliti, desain penelitian yang digunakan adalah desain deskriptif, populasi penelitiannya adalah orang tua klien demam berdarah yang memenuhi kriteria inklusi, alat ukur yang digunakan adalah kuesioner. Metode sample diambil secara consecutive sampling sebanyak 28 responden. Hasil dari penelitian ini menggambarkan tingkat pengetahuan responden tentang upaya pencegahan demam berdarah termasuk dalam kategori pengetahuan baik $7 \%$, pengetahuan cukup 56\%, pengetahuan kurang $37 \%$. Adanya responden dengan pengetahuan kurang tentang upaya pencegahan demam berdarah dapat disebabkan karena mereka kurang mendapat informasi tentang hal-hal tersebut. Selama ini informasi yang mudah didapatkan atau yang sebarkan melalui media masa, cetak dan elektronik maupun melalui pendidikan informal terbatas pada cara pencegahan demam berdarah yang disosialisasikan oleh pemerintah.
\end{abstract}

Kata Kunci : Pengetahuan, Upaya Pencegahan Demam Berdarah.

\section{ABSTRACT}

Every year number of dengue patients experiences this improvement and case mortality also always experiences improvement, this thing is because of lack of knowledge of old fellow about prevention effort of dengue. co-signature prevention effort is step most importantly for patient causing earns soon is conducted action. Based on writer the thing interests to take title" Image Of Level Of Knowledge of Old Fellow About Prevention Effort of Dengue To Child Of Age ( 6-12 years) in Pediatric Departement of William Booth Hospital Surabaya". Based on purpose of researcher, research design applied is descriptive design, population of its(the research is dengue client old fellow fulfilling criterion inklusi, graduated apparatus applied is questionaire. Sample method is taken in consecutive sampling 28 responders. Result from this research depicts level of knowledge of responder about prevention effort of dengue included in knowledge category is good $7 \%$, knowledge of enough 56\%, less knowledge of 37\%. Existence of responder with knowledge is less about prevention effort of dengue can be caused by they unable to get information about the things. Till now information which is easy got or propagating through media a period, print and electronic and or through informal education limited to way of prevention of dengue socialized by government.

Keyword $\quad$ : Knowledge, Prevention Effort of Dengue. 


\section{Pendahuluan}

Pengetahuan adalah hasil dari tahu dan ini terjadi setelah orang melakukan penginderaan terhadap suatu objek tertentu yakni penginderaan penciuman, rasa, dan raba (Notoatmodjo, 1993). Upaya pencegahan adalah suatu usaha atau tindakan untuk mencegah sesuatu agar tidak terjadi, salah satu usaha atau tindakan tersebut adalah dengan melihat perilaku seseorang terhadap kondisi lingkungan sekitarnya. Perilaku seseorang sangat mempengaruhi lingkungan dalam upaya pencegahan penyebaran virus dengue adalah dengan menciptakan suatu lingkungan yang sehat, sering kali masih ditemukan adanya penyakit Demam Berdarah (DHF) yang masuk kedalam tubuh manusia melalui nyamuk Aides Aegepty (Cristantie Effendy, 1955). Pada umumnya orang tua kurang menanggapi terhadap informasi yang disampaikan melalui media masa, seperti televisi maupun koran tentang bahaya demam berdarah serta upaya pencegahan terhadap berkembangnya virus Dengue penyebab demam berdarah, seringkali informasi ini dapat disampaikan melalui pihak rumah sakit.

Insiden demam berdarah meningkat secara drastis dan berdasarkan data yang di dapat dari rekam medik RS William Booth Surabaya pada tahun 2008, untuk Ruang Mirah Delima terdapat sekitar 40 orang dan pada tahun 2009 sekitar 56 orang menderita demam berdarah. Dari studi pendahuluan dengan 30 orang anak yang menderita demam berdarah di Ruang Mirah Delima RS William Booth Surabaya ada sekitar 3 orang tua yang mengetahui bagaimana upaya pencegahan terhadap penyakit demam berdarah, tetapi sebagian besar yaitu sekitar 21 orang tua tidak mengahui upaya pencegahan demam berdarah.

Secara kronologis proses penyakit demam berdarah ini dimulai dari nyamuk Aides Aegepty yang tidak bervirus menggigit dan menghisap darah seorang yang terkena demam berdarah dengue. Nyamuk yang telah terinfeksi tersebut menggigit orang sehat dan memindahkan virusnya bersama air ludah kedalam tubuh. Pada saat ini virus menginfeksi sel-sel darah putih serta kelenjar getah bening kemudian masuk ke sistem sirkulasi darah. Pada saat itu terjadi pertempuran anti body dan virus dengue sehingga terjadi gejala demam tinggi antara $39^{\circ} \mathrm{C}$ sampai $40^{\circ} \mathrm{C}$, akibat pertempuran tersebut terjadi penurunan trombosit dan bocornya pembuluh darah sehingga plasma darah mengalir keluar. Pada fase ini muncul gejala-gejala pada tubuh,biasanya diikuti oleh sindrom syok.

Untuk mengantisipasi terjadinya penyakit demam berdarah ini salah satu cara adalah meningkatkan pemberian informasi tentang pencegahan penyakit demam berdarah. Informasi ini adalah suatu tindakan untuk merangsang agar bisa menjaga kebersihan lingkungan dengan tindakan 3M (Menguras, Menutup, Mengubur), foging, pemberian abate, dan pemberian ikan pemakan jentik. Berdasarkan solusi tersebut diatas maka peneliti ingin mengetahui sejauh mana upaya orang tua untuk mencegah demam berdarah.

\section{Metode}

Berdasarkan ruang lingkup dan
tujuan penelitian, maka peneliti menggunakan metode deskriptif. Populasi dalam penelitian ini adalah semua orang tua yang anaknya menderita penyakit demam berdarah di Ruang Mirah Delima RS William Booth Surabaya .Jumlah populasi dalam penelitian sebanyak 30 responden.

\section{Hasil}

\section{Data Demografi.}

Data demografi ini menggambarkan tentang karakteristik responden berdasarkan :

Pendidikan.

Berdasarkan hasil pendataan karakteristik tingkat pendidikan responden didapatkan data sebagai berikut :

Tabel 1 Karakteristik responden berdasarkan pendidikan di Ruang Mirah Delima RS William Booth Surabaya

\begin{tabular}{|l|c|c|}
\hline $\begin{array}{c}\text { Tingkat } \\
\text { pendidikan }\end{array}$ & jumlah & $\begin{array}{r}\text { Prosentase } \\
(\%)\end{array}$ \\
\hline S D & 1 & $4 \%$ \\
\hline S M P & 6 & $21 \%$ \\
\hline S M A & 14 & $50 \%$ \\
\hline AKADEMI / PT & 7 & $25 \%$ \\
\hline Jumlah & 28 & $100 \%$ \\
\hline
\end{tabular}


Berdasarkan tabel menunjukkan tingkat pendidikan responden sebagian besar adalah SMA sebanyak 14 responden (50\%).

\section{Pekerjaan}

Berdasarkan hasil pendataan karakteristik pekerjaan responden didapatkan data sebagai berikut :

Tabel 2 Karakteristik responden berdasarkan pekerjaan di Ruang Mirah Delima RS William Booth Surabaya

\begin{tabular}{|l|c|c|}
\hline \multicolumn{1}{|c|}{ Pekerjaan } & Jumlah & $\begin{array}{c}\text { Prosentase } \\
(\%)\end{array}$ \\
\hline Buruh & 2 & $8 \%$ \\
\hline Swasta & 14 & $50 \%$ \\
\hline PNS / ABRI & 6 & $21 \%$ \\
\hline Tidak bekerja & 6 & $21 \%$ \\
\hline \multicolumn{1}{|c|}{ Jumlah } & 28 & $100 \%$ \\
\hline
\end{tabular}

Berdasarkan tabel diatas menunjukkan sebagian besar responden bekerja sebagai pegawai swasta yaitu sebanyak 14 responden $(50 \%)$.

Karakteristik responden berdasarkan umur.

Berdasarkan hasil pendataan karakteristik umur responden didapatkan data sebagai berikut :

Tabel 3 Karakteristik responden berdasarkan umur di Ruang Mirah Delima RS William Booth Surabaya

\begin{tabular}{|c|c|c|}
\hline m u r & Jumlah & $\begin{array}{c}\text { Prosentase } \\
(\%)\end{array}$ \\
\hline $18-23$ tahun & 0 & $0 \%$ \\
\hline $24-29$ tahun & 7 & $25 \%$ \\
\hline $30-35$ tahun & 20 & $71 \%$ \\
\hline$>36$ tahun & 1 & $4 \%$ \\
\hline Jumlah & 28 & $100 \%$ \\
\hline
\end{tabular}

Berdasarkan tabel diatas menunjukkan sebagian besar responden berusia 30-35 tahun yaitu sebanyak 20 responden $(71 \%)$ Karakteristik responden agama didapatkan data sebagai berikut:

Tabel 4 Karakteristik responden berdasarkan agama di Ruang Mirah Delima RS William Booth Surabaya

\begin{tabular}{|l|c|c|}
\hline \multicolumn{1}{|c|}{ Agama } & Jumlah & $\begin{array}{c}\text { Prosentase } \\
(\%)\end{array}$ \\
\hline Islam & 13 & $46 \%$ \\
\hline Kristen & 7 & $25 \%$ \\
\hline Katholik & 4 & $14 \%$ \\
\hline Hindu & 3 & $11 \%$ \\
\hline Budha & 1 & $4 \%$ \\
\hline Jumlah & 28 & $100 \%$ \\
\hline
\end{tabular}

Berdasarkan tabel diatas menunjukkan agama responden sebagian besar adalah Islam yaitu sebanyak 13 responden (46\%).

Karakteristik responden berdasarkan jenis kelamin didapatkan data sebagai berikut :

Tabel.5 Karakteristik responden berdasarkan jenis kelamin di Ruang Mirah Delima RS William Booth Surabaya

\begin{tabular}{|l|c|c|}
\hline Jenis Kelamin & Jumlah & $\begin{array}{c}\text { Prosentase } \\
(\%)\end{array}$ \\
\hline Laki-laki & 10 & $36 \%$ \\
\hline Perempuan & 18 & $64 \%$ \\
\hline Jumlah & 28 & $100 \%$ \\
\hline
\end{tabular}

Berdasarkan tabel diatas menunjukkan jenis kelamin responden sebagian besar adalah perempuan yaitu sebanyak 18 responden $(64 \%)$.

\section{Data khusus}

Data khusus ini menggambarkan tingkat pengetahuan orang tua tentang upaya pencegahan demam berdarah.

Karakteristik responden berdasarkan tingkat pengetahuan orang tua tentang upaya pencegahan demam berdarah.

Berdasarkan hasil pendataan katakteristik tingkat pengetahuan orang tua tentang upaya pencegahan demam berdarah didapatkan data sebagai berikut.

Tabel 6 Tingkat pengetahuan responden tentang upaya pencegahan demam berdarah di Ruang Mirah Delima RS William Booth Surabaya

\begin{tabular}{|l|c|c|}
\hline $\begin{array}{c}\text { Tingkat } \\
\text { Pengetahuan }\end{array}$ & Jumlah & $\begin{array}{c}\text { Prosentase } \\
(\%)\end{array}$ \\
\hline Baik & 2 & $7 \%$ \\
\hline Cukup & 15 & $54 \%$ \\
\hline Kurang & 11 & $39 \%$ \\
\hline Jumlah & 28 & $100 \%$ \\
\hline
\end{tabular}

Berdasarkan tabel diatas dapat dilihat sebagian besar responden berpengetahuan cukup sebanyak 15 responden dengan prosentase $54 \%$.

Tabulasi silang antara tingkat pengetahuan dengan tingkat pendidikan. 
Tabel 7 Tabulasi silang antara tingkat pengetahuan dengan tingkat pendidikan orang tua tentang upaya pencegahan deman berdarah pada anak usia (6-12 tahun) di Ruang Mirah Delima RS William Booth Surabaya

\begin{tabular}{|c|c|c|c|c|c|c|}
\hline \multirow[t]{2}{*}{ Pendidikan } & \multicolumn{6}{|c|}{ Tingkat Pengetahuan } \\
\hline & Baik & $\%$ & $\begin{array}{c}\text { Cuku } \\
\text { p }\end{array}$ & $\%$ & $\begin{array}{c}\text { Kura } \\
\text { ng }\end{array}$ & $\%$ \\
\hline S D & 0 & $0 \%$ & 0 & $\begin{array}{l}0 \\
\%\end{array}$ & 1 & $\begin{array}{c}10 \\
0 \\
\%\end{array}$ \\
\hline S M P & 0 & $0 \%$ & 3 & $\begin{array}{l}50 \\
\%\end{array}$ & 4 & $\begin{array}{l}66 \\
\%\end{array}$ \\
\hline S M A & 2 & $\begin{array}{l}14 \\
\%\end{array}$ & 8 & $\begin{array}{l}57 \\
\%\end{array}$ & 4 & $\begin{array}{l}29 \\
\%\end{array}$ \\
\hline $\begin{array}{l}\text { AKADEMI/ } \\
\text { PT }\end{array}$ & 0 & $0 \%$ & 4 & $\begin{array}{l}57 \\
\%\end{array}$ & 2 & $\begin{array}{l}28 \\
\%\end{array}$ \\
\hline Jumlah & 2 & & 15 & & 11 & \\
\hline
\end{tabular}

Berdasarkan tabel tabulasi silang diatas terlihat bahwa sebagian besar berpengetahuan cukup adalah SMA sebanyak 8 responden $(57 \%)$

Tabulasi silang antara tingkat pengetahuan dengan pekerjaan.

Tabel 8 Tabulasi silang antara tingkat pengetahuan dengan pekerjaan orang tua tentang upaya pencegahan deman berdarah pada anak usia (6-12 tahun) di Ruang Mirah Delima RS William Booth Surabaya
Tabulasi silang antara tingkat pengetahuan dengan umur.

Tabel 9 Tabulasi silang antara tingkat pengetahuan dengan umur orang tua tentang upaya pencegahan deman berdarah pada anak usia (612 tahun) di Ruang Mirah delima RS William Booth Surabaya

\begin{tabular}{|l|c|c|c|c|c|c|}
\hline \multirow{2}{*}{ U m u r } & \multicolumn{6}{|c|}{ Tingkat Pengetahuan } \\
\cline { 2 - 7 } & $\begin{array}{c}\text { Bai } \\
\mathrm{k}\end{array}$ & $\begin{array}{c}\% \\
\mathrm{Cu} \\
\mathrm{ku}\end{array}$ & $\%$ & $\begin{array}{c}\text { Kur } \\
\text { ang }\end{array}$ & $\%$ \\
\hline $\begin{array}{l}18-23 \\
\text { tahun }\end{array}$ & 0 & $0 \%$ & 0 & $0 \%$ & 0 & $0 \%$ \\
\hline $\begin{array}{l}24-29 \\
\text { tahun }\end{array}$ & 1 & 14 & 5 & 71 & 1 & $14 \%$ \\
\hline $\begin{array}{l}30-35 \\
\text { tahun }\end{array}$ & 1 & $5 \%$ & 9 & $\begin{array}{c}45 \\
\%\end{array}$ & 10 & $50 \%$ \\
\hline$>36$ tahun & 0 & $0 \%$ & 1 & $\begin{array}{c}10 \\
0 \%\end{array}$ & 0 & $0 \%$ \\
\hline \multicolumn{1}{|c|}{ Jumlah } & 2 & & 15 & & 11 & \\
\hline
\end{tabular}

Berdasarkan tabel tabulasi silang diatas terlihat bahwa sebagian besar berpengetahuan kurang adalah usia 30-35 tahun sebanyak 10 responden (50\%)

Tabulasi silang antara tingkat pengetahuan dengan agama

Tabel 10 Tabulasi silang antara tingkat pengetahuan dengan agama orang tua tentang upaya pencegahan deman berdarah pada anak usia (6-12 tahun) di Ruang Anak Mirah Delima RS William Booth Surabaya

\begin{tabular}{|c|c|c|c|c|c|c|c|c|c|c|c|c|}
\hline \multirow{2}{*}{$\begin{array}{c}\text { Pekerjaa } \\
n\end{array}$} & \multicolumn{5}{|c|}{ Tingkat Pengetahuan } & \multirow{2}{*}{\multicolumn{7}{|c|}{$\begin{array}{l}\text { Mirah Delima RS William Booth } \\
\text { Surabaya }\end{array}$}} \\
\hline & \multirow{3}{*}{$\begin{array}{c}\text { Baik } \\
0\end{array}$} & $\%$ & Cukup & $\%$ & Kurang & & & & & & & \\
\hline \multirow[t]{2}{*}{ Buruh } & & \multirow{2}{*}{$\begin{array}{l}0 \\
\%\end{array}$} & \multirow[t]{2}{*}{2} & \multirow{2}{*}{$\begin{array}{l}1 \\
0 \\
0 \\
\%\end{array}$} & \multirow[t]{2}{*}{0} & \multirow{2}{*}{$\rho_{0}$ Agama } & \multicolumn{6}{|c|}{ Tingkat Pengetahuan } \\
\hline & & & & & & & $\begin{array}{c}\text { Bai } \\
k\end{array}$ & $\%$ & $\begin{array}{l}\mathrm{Cu} \\
\mathrm{ku}\end{array}$ & $\%$ & $\begin{array}{c}\text { Kura } \\
\text { ng }\end{array}$ & $\%$ \\
\hline \multirow[t]{2}{*}{ Swasta } & 2 & 1 & 9 & 6 & 3 & 2 Islam & 0 & $0 \%$ & $\frac{\mathrm{p}}{5}$ & 38 & 8 & 62 \\
\hline & & $\begin{array}{l}4 \\
\%\end{array}$ & & $\begin{array}{l}4 \\
\%\end{array}$ & & & & & & $\%$ & & $\%$ \\
\hline \multirow{2}{*}{$\begin{array}{l}\text { PNS/ } \\
\text { ABRI }\end{array}$} & \multirow[t]{2}{*}{0} & \multirow{2}{*}{$\begin{array}{l}0 \\
\%\end{array}$} & \multirow[t]{2}{*}{3} & 5 & \multirow[t]{2}{*}{3} & \multirow{2}{*}{$\begin{array}{l}5^{K} \text { Kristen } \\
\phi_{0} \text { Katholik }\end{array}$} & 0 & $0 \%$ & 5 & $\begin{array}{l}71 \\
\%\end{array}$ & 2 & $\begin{array}{l}29 \\
\%\end{array}$ \\
\hline & & & & $\%$ & & & 2 & $50 \%$ & 2 & 50 & 0 & $0 \%$ \\
\hline $\begin{array}{l}\text { Tidak } \\
\text { bekerja }\end{array}$ & 0 & $\begin{array}{l}0 \\
\%\end{array}$ & 1 & $\begin{array}{c}3 \\
3 \\
\%\end{array}$ & 5 & $3_{0}^{3}$ Hindu & 0 & $0 \%$ & 2 & $\begin{array}{l}\% \\
67 \\
\%\end{array}$ & 1 & $\begin{array}{l}33 \\
\%\end{array}$ \\
\hline Jumlah & 2 & & 15 & & 11 & Budha & 0 & $0 \%$ & 1 & 100 & 0 & $0 \%$ \\
\hline $\begin{array}{l}\text { 3erdasarkan } \\
\text { erlihat }\end{array}$ & $\begin{array}{l}\text { tabel } \\
\text { ahwa }\end{array}$ & \multicolumn{4}{|c|}{$\begin{array}{c}\text { tabulasi silang } \begin{array}{c}\text { diatas } \\
\text { sebagian }\end{array} \\
\text { besar }\end{array}$} & Jumlah & 2 & & 15 & & 11 & \\
\hline
\end{tabular}

berpengetahuan cukup adalah pekerjaan swasta sebanyak 9 responden (64\%) 
Berdasarkan tabel tabulasi silang diatas, terlihat bahwa sebagian besar responden berpengetahuan kurang sebanyak 8 orang $(62 \%)$ beragama Islam.

Tabulasi silang antara tingkat pengetahuan dengan jenis kelamin.

Tabel 11 Tabulasi silang antara tingkat pengetahuan dengan jenis kelamin orang tua tentang upaya pencegahan deman berdarah pada anak usia (6-12 tahun) di Ruang Mirah Delima RS William Booth Surabaya Tabulasi silang antara tingkat pengetahuan dengan jenis kelamin

\begin{tabular}{|c|c|c|c|c|c|c|}
\hline \multirow{2}{*}{$\begin{array}{c}\text { Jenis } \\
\text { kelamin }\end{array}$} & \multicolumn{6}{|c|}{ Tingkat Pengetahuan } \\
\hline & Baik & $\%$ & Cukup & $\%$ & $\begin{array}{l}\text { Kur } \\
\text { ang }\end{array}$ & $\%$ \\
\hline Laki-laki & 1 & $\begin{array}{l}10 \\
\%\end{array}$ & 6 & $\begin{array}{l}60 \\
\%\end{array}$ & 3 & $\begin{array}{l}30 \\
\%\end{array}$ \\
\hline $\begin{array}{l}\text { Perempu } \\
\text { an }\end{array}$ & 1 & $6 \%$ & 9 & $\begin{array}{l}50 \\
\%\end{array}$ & 8 & $\begin{array}{l}44 \\
\%\end{array}$ \\
\hline Jumlah & 2 & & 15 & & 11 & \\
\hline
\end{tabular}

Berdasarkan tabel tabulasi silang diatas terlihat bahwa sebagian besar responden berpengetahuan cukup yaitu sebanyak 9 $(50 \%)$ berjenis kelamin perempuan.

\section{Pembahasan}

Berdasarkan hasil penelitian dan data dari tabel 10 : terlihat bahwa tingkat pengetahuan orang tua tentang upaya pencegahan demam berdarah di Ruang Mirah Delima RS William Booth Surabaya terbanyak berpengetahuan cukup yaitu sebanyak 15 responden (54\%), berpengetahuan kurang sebanyak 11 responden $(39 \%)$ dan berpengetahuan baik sebanyak 2 responden (7\%).

Menurut Notoatmodjo

pengetahuan dipengaruhi oleh faktor intrinsik dan ekstrinsik. Faktor intrinsik meliputi usia, lingkungan, pendidikan, agama dan sosial ekonomi. Faktor-faktor tersebut dapat mempengaruhi pengetahuan tetapi tidak mutlak, tergantung kepercayaan individu tersebut dalam menerima informasi, sehingga banyak pula pengetahuan yang dimilikinya. Hal ini disebabkan karena pengetahuan tentang upaya pencegahan demam berdarah sangat mudah didapatkan melalui petugas kesehatan, media masa baik secara langsung maupun tidak langsung. Adanya responden dengan pengetahuan kurang tentang upaya pencegahan demam berdarah dapat disebabkan kerena mereka kurang mendapat informasi tentang cara pencegahan deman berdarah dan juga disebabkan oleh faktor lingkungan misalnya : lingkungan yang kotor dan jarang dibersihkan.

Berdasarkan tabel 7 tentang karakteristik responden berdasarkan pendidikan didapatkan terbanyak berpendidikan SMA yaitu sebanyak 14 responden (50\%). Menurut Notoadmodjo (1997), pendidikan adalah proses belajar yang layak, semakin tinggi tingkat pendidikan seseorang maka semakin tinggi pengetahuannya, sebaliknya semakin rendah tingkat pendidikan seseorang dapat menghambat penerimaan informasi. Tidak semua orang yang berpendidikan tinggi pengetahuannya tinggi juga, ini dikarenakan oleh banyak faktor yaitu salah satunya : lingkungan, sosial dan kurang menerima informasi.

Berdasarkan tabel 8 menunjukkan bahwa karakteristik responden berdasarkan pekerjaan didapatkan terbanyak pekerjaan swasta yaitu sebanyak 14 responden (50\%). Menurut Notoadmodjo (1997) pekerjaan atau sosial ekonomi adalah keadaan ekonomi keluarga yang relative mencukupi akan mampu menyediakan fasilitas yang diperlukan untuk mendapatkan pengetahuan. Seseorang yang bekerja belum tentu memiliki pengetahuan yang baik dibandingkan dengan orang yang tidak bekerja, orang yang tidak bekerja dapat memiliki pengetahuan yang baik yaitu dengan orang lain, sehingga mereka dapat saling bertukar informasi dan mereka mempunyai waktu yang banyak untuk mengikuti penyuluhan kesehatan, meskipun mereka bekerja ternyata waktu yang digunakan masih ada.

Berdasarkan tabel 9 : tentang karakteristik berdasarkan umur didapatkan terbanyak responden berumur 30-35 tahun, sebanyak 20 orang (71\%). Menurut Notoadmodjo (2003) mengatakan bahwa semakin cukup umur seseorang, maka tingkat kematangan dan kekuatan seeorang akan lebih matang dalam berfikir dan semakin bertambahnya usia seseorang semakin dapat menggunakan koping yang dihadapi. Namun disisi lain semakin tua umur seseorang semakin banyak pengalaman yang didapatkan tetapi tidak semuanya dapat diproses dalam pikiran dengan baik sebab 
pada usia tertentu seseorang mengalami penurunan kemampuan dalam menerima informasi yang diterima.

Simpulan

Dapat disimpulkan tingkat pengetahuan orang tua tentang upaya pencegahan demam berdarah berada pada tingkat pengetahuan cukup sebanyak 15 responden (54\%).

\section{DAFTAR PUSTAKA}

Asih, Yasmin. 1998. Diagnosis Pengobatan, Pencegahan dan Pengendalian Demam Berdarah Dengue. Edisi 2. Jakarta : EGC

Capenito Lynda Juall. 1998. Diagnosa Keperawatan Edisi 6, EGC : Jakarta

Effendi Kristantie, Skp. (1995). Perawatan Pasien DHF, EGC : Jakarta

http://www.google.com.mecastore/DHF/peny akit.DHF.com

Notoatmodjo. 2005. Metodologi Penelitian Kesehatan. Jakrta : PT.Renika Cipta

Nursalam. 2003. Konsep dan Penerapan Metodologi Penelitian Ilmu Keperawatan. Jakarta : Salemba Medika

Nursalam dan Pariani. 2001. Pendekatan Praktis Metodologi Riset Keperawatan. Jakarta : CV Info Medika

Pedoman Skripsi, Tesis dan Instrumen Penelitian, Salemba Medika : Jakarta

Setiadi. 2007. Konsep dan Penulisan Riset Keperawatan. Jogyakarta : Graha Ilmu

Sri Rezeki H.Hadinegoro. 1999. Demam Berdarah Dengue. Jakarta : Fakultas Kedokteran Univesitas Indonesia. 